the discussions by short historical accounts of the development of our knowledge on the various topics.

The second part of the book is devoted to the development of special organs, and here the author is more confined to the mammals and gives less consideration to the other vertebrates. The method of consideration is that of the study of organs according to their origin in the different layers of the body. These are considered, therefore, under four heads. The rrgans of the endoderm include the alimentary system in general; the organs of the ectoderm include the nervous system; the organs of the middle germ-layer include the muscles, the urinary and sexual organs. Professor Hertwig's views of the body cavity lead him to the formulation of a fourth layer of the vertebrate embryo, which he calls the intermediate layer or mesenchyme. and the last section of the text-book studies the development of the organs from this mesenchyme. These, according to Hertwir, are the circulatory system and the skeleton.

The special merits of this book are the logical treatment and its consideration of the embryological facts as parts of a system. The general method of the treatment of the subject is a comparative rather than a physiological one, and the text-book will give the student an insight into comparative anatomy but very little consideration of the physiology of the developing embryo In one of the two sections, it is true, the mechanics of development are considered, but in general, the text-book is a morphological rather than a physiological study. This is, of course, a natural outcome of the line of work in which Professor Hertwig has been so successfully engaged for so many years.

Not the least valuable part of the book consisis in the abundant literature. Some fifty pages are devoted to giving the titles and references to the most important papers of vertebrate embryology. The book has, also, another feature, somewhat rare in German scientific books, but of extreme value to students, in the form of short, logical, but intelligible summaries at the end of every section giving in outline the important conclusions.
On the whole, the text-book of Professor Hertwig is probably the best general study of vertebrate embryology that has appeared in the English language up to the presen: time, and it can be most heartily recommended to all interested in these subjects.

Chemical Lecture Experiments. Non-Metallic Elements. By G. S. Newth, F.I.C. London and New York, Longmans, Gireen $\&$ Co. 323 p. $8^{\circ}$.

A воок of chemical lecture experiments, carefully classified and systematically arranged, cannot but be welcome to many. Moreover, a book from a practised hand, such as Mr. G. S. Newth, chemical lecture demonstrator in the Royal College of Science. South Kensington, has a particular value in that its experiments are so given as to be readily repeated and are not, as is of ten the case, merely a statement of the reaction with a few confusing details. Mr. Newth has chosen his experiments well and has described them in clear concise language. The book has a twofold purpose in easing the labors of the lecturer and of the student alike. For the former it supplies a useful repertoire of lec. ture experiments and will surely be gladly recei ved, removing, as it does entirely, the humdrum search for such examples and reactions as can be suitably and successfully demonstrated on the lecture table. This, as every lecturer knows, is by no means a small item in the preparation of a lecture, and, moreover, being important, it cannot be carelessly or hastily done. The experiment must be quickly and successfully performed or the interest of the student is turned to illy-concealed ridicule, and the lecturer is, so to speak, lost.

To the student the book appeals in providing a ready reference to serve as a companion in the lecture room, and in supplying the deficiencies of his notes. Indeed. it may in most cases entirely relieve him of the necessity of taking notes upon the experiments themselves, drawings of the apparatus, etc., and will thus be enabled to devote his attention to the explanatiog

CALENDAR OF SOCIETIES.
Anthropological Society, Washington.
March 14. - Major John W. Powell, A
Study in Psychology.
Geological Society, Washington.

Geological Society, Washington.

March 2. - G. K. Gilbert, An Open Fiss. ure; G. P. Merrill, Remarks on the So-Called Onyx Marbles or Travertines; C. D. Walcott, The Algonkian Rocks of the Grand Canyon of the Colorado.

Chemical Society, Washington.

Feb. 9. - W. H. Krug, A New Method for Estimating Furfurol-Hydrazone; E. E. Ewell and H. W. Wiley, On Some Prolucts of the Cassava Plant Professor Wiley describes the plant as it occurs in Florida, and says there is every reason to believe that, if the attention of capitalists is called to it, a large quantity of land now covered with pines could be profitably cleared and devoted to the cultivation of the cassava plant. A minimum average yield is four tons of roots per acre, which may be readily increased by proper fertilization to eight or ten tons per acre. Maize could not compete with cassava if the same intelligent cultiva tion is applied, and there is a prospect that the cassava will eventually take the place of maize in the production of starch, glucose, etc.

March 9.-W. D. Bigelow and K. P. McElroy, Determination of Lactose in Presence of Invert Sugar and Sucrose.
Philosophical Society, Washington.

March 18.- W. H. Holmes, Traces of Glacial Man in the Trenton Gravels; Asaph Hall, The Planet Mars.

\section{THE RADIOMETER.}

\section{BY DANIEL S. TROY.}

This contains a discussion of the reasons for their action and of the phenomena presented in Crookes' tubes.

Price, postpaid, 50 cents.

N. D. C. HODGES, 874 Broadway, N. Y.

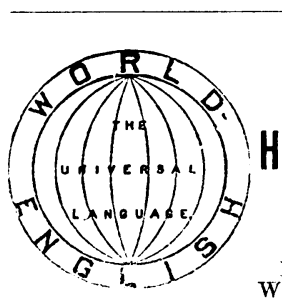

White, of Cornell University,
says: "I believe that the highest interests of Chr istian civilization and of humanity would be served tian eivilization
by its adoption."
"So set down,

"So set down, our tongue is the best for the world uThe idea of Mr. Bell has muc

and the presentation is charmingly clear."

can. Phila. The result is a languare which cannot fail to "eet with acceptance."-Boston Traveller.

"World.English deserves the careful consideration Sent, postpaid, on receipt of price.

N. D. C. HODGES, 874 Broadway, New York.

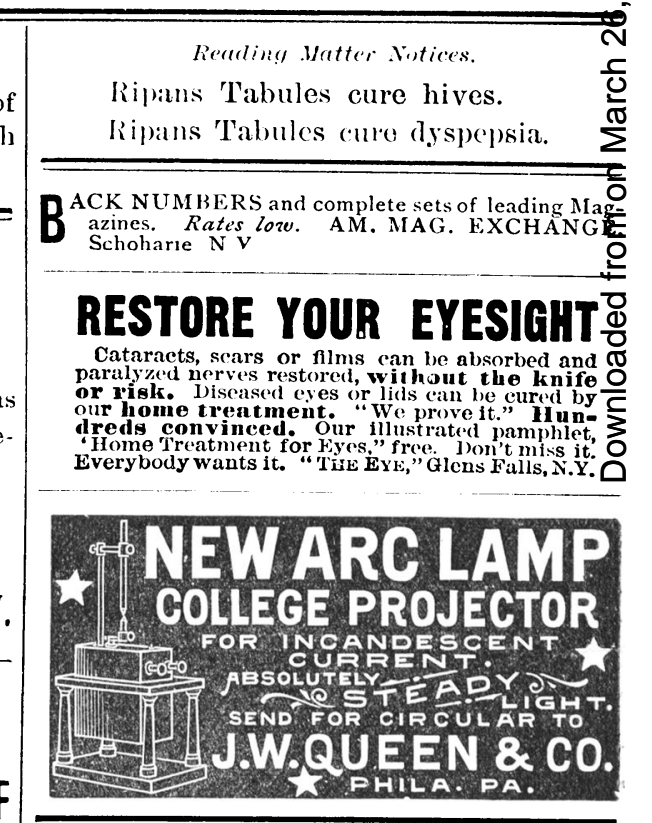

A TEMPORARY BINDER

for Science is now ready, and will be mailed postpaid on receipt of 75 cents.

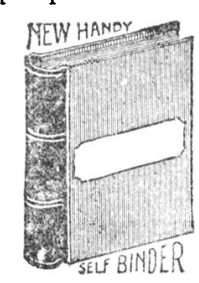

This binder is strong, durable and elegant, hats gilt side-title, and allow: the opening of the pages perfecily flat. Any number can bo taken out or replaced without dis-

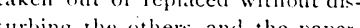
are not the chers and the paper are not mutilated for subsecpuent permanent binding. Filed in thibinder, Science is always convenient for reference.

N. D. C. HODGES, 874 Broadway, N. Y. 
and arguments of the lecturer. For the further aid of the student, equations are given representing the various reactions described, and every reasonable detail of the operation is recorded. Not only for the student in the lecture room is the book valuable, but also for the many who have not the advantage of college demonstration and who are compelled to rely largely upon their own resources. For the convenience of such teachers as may not have ready access to books of reference, Mr. Newth has added in the form of an appendix a number of important and useful tables, thirty-four in all, not often found in the sinaller works on chemistry.

C. P.

An Introduction to Qualitative Chemical Analysis by the Inductive Method. A Laboratory Manual for Colleges and High Schools. By Delos Fall, M.S. Boston and New York,

Leach, Shewell \& Sanborn. $8^{\circ}$.

IN this age of text-books it is difficult to be original, and the most that our authors have aimed at is perfection and revision of arrangement. Mr. Delos Fall, M.S., Professor of Chemistry at Albion College, has, however, recently given to the student of chemistry a new manual of qualitative analysis decidedly unique in its character. As he asserts in his prefatory note, this manual is designed to impart but little chemical truth directly, aiming rather to lead the student to gain that truth himself as nearly as possible at first hand and as a product of his own thinking. A preliminary chapter intended for both the student and the instructor gives the general plan of the book and describes the method to be used. This consists essentially in leading questions calculated to bring the student on by his own research from the fundamental ideas of chemical theory to the more advanced practical application of his knowledge to systematic qualitative analysis.

The plan as described by the author is a combination of (1) original investigation and (2) reference to authorities. "In the beginning (1) will be a very small factor and (2) correspondingly large. As experience in manipulation. observation, and interpretation increases (1) will increase and the necessary dependence on (2) will decrease. To the experienced chemist (1) is very large and (2) very small; in other words, he is his own authority." Under the guidance of an able instructor the book will be most valuable, and in such a case will, as the author has himself demonstrated, produce accurate, enthusiastic, and independent students.

C. P.

The Batrachians and Reptiles of the State of Indiana. Bs OLIVER P. HAY. Indianapolis, William P. Burford, Printer and Binder.

THE present work consists of a list of the reptiles and batrachians found in the State of Indiana, with a description of their characteristics and with analytical keys for the determination of species. The work describes 81 species in all, and is accompanied by a few plates illustrating the subject. The design of the author is to make a key which shall be usable by those who are not specialists, and he has therefore appended a glossary, explaining the use of all scientific terms, and his general method of treatment is such as to make the book intelligible even to a novice.

The Birds of Indiana. By Amos W. Butler. From the Transactions of the Indiana Horticultural Society for $\mathbf{1 8 9 0 .}$

THIs little pamphlet consists simply of a list of the birds found in Indiana, either as residents or as temporary migrants. No characteristics of species are given, although a large number of illustrations are inserted, taken from Coues's "Key to North American Birds."

THE price of Dr. Sternberg's work on bacteriology, reviewed in Science, Feb. 24, should have been stated as $\$ 8$, cloth; and $\$ 9$, sheep; Wm. Wood \& Co., New York, publishers.

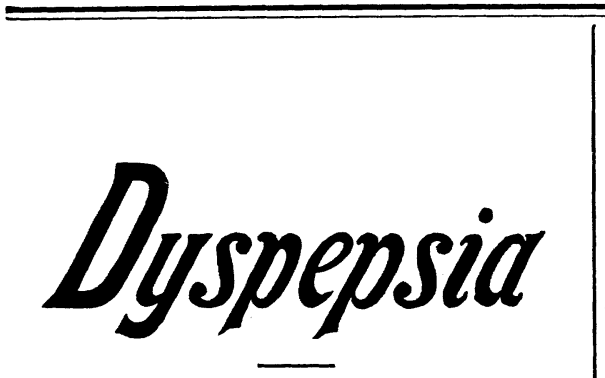

Dr. T. H. Andrews, Jefferson Medical College, Philadelphia, says of Horsford's Acid Phosphate.

"A wonderful remedy which gave me most gratifying results in the worst forms of dyspepsia."

It reaches various forms of Dyspepsia that no other medicine seems to touch, assisting the weakened stomach, and making the process of digestion natural and easy.

Descriptive pamphlet free on application to Rumford Chemical Works, Providence, R. I

Beware of Substitutes and Imitations.

For sale by all Druggists.

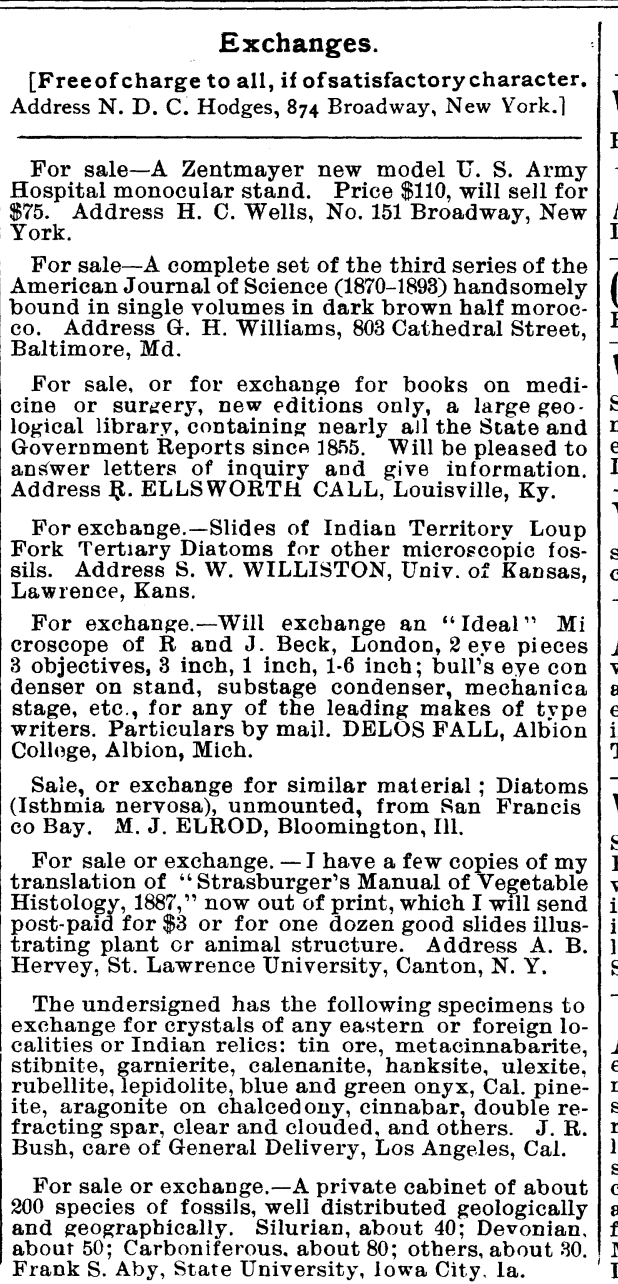

Wants

W ANTED-Second-hand copy Tryon's Systematic Conchology. Please quote condition, date, price.
H. L. Osborn, Hamline University, St. Paul, Minn. COMPETENT TEACHER of botany in college
or university is open to engagement. Address
L., Box 86, Rochester, Mich.

CAN any one inform me as to the age to which cats have lived? I have one twenty years old.
Edward D. Webb, 132 w. Eighty-first St., New York W ANTED - Second-hand. Foster's Physiology, Sedgwick's Zoology. Flower's Osteology of Mammalia, Vine's Physiology of Plants. Please state editions and prices asked and address Richard Lees Brampton, Ontario, Canada

$W_{\text {seven volumes. American Journal of Conchology, }}^{\text {ANTED }}$ seven volumes. Parties having these for sale will please address the undersigned, stating
condition and price. R.Ellsworth Call,Louisville, $\mathbf{K y}$.

A GRADUATE ENGINEER will give instruction A evenings in geometry, trigonometry and surveying, mechanics, physics, mechanical drawing and general engineering construction. Five years experience in field and editorial work on engineer Tribune Building, New York.
Trished. C. S. H., 102 $W^{\text {ANTED.-By well - qualified and experienced }}$ School of Mines, London, aged 26 (at present in England), a mastership in technical college or university for any of the following subjects: Engineer ing sciences, geology and mineralogy, physics, chem istry and metallurgy, etc.. etc. Can provide excel. Sussex St., Rochdale, England.

A GRADUATE of the University of Pennsylvania and a practical mineralogist of twenty years net of 25,000 specimens, all named, with about the same number of duplicates, in minerals, crystais, ocks, gems, fossils, shells, archæological and ethno siring a fine outfit for study. The owner will in
sing crease the cabinet to 50,000 specimens in two year and will act as curator. Correspondeace solicited from any scientific institution. J. W. Hortter M.D., Ph.D., San Francisco, Cal., General P. O.
Delivery. 